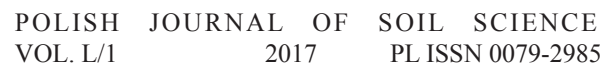

DOI: $10.17951 / \mathrm{pjss} / 2017.50 .1 .121$

\title{
MAŁGORZATA WŁODARCZYK*, HANNA SIWEK* \\ THE INFLUENCE OF HUMIDITY AND SOIL TEXTURE ON THE DEGRADATION PROCESS OF SELECTED HERBICIDES IMMOBILIZED IN ALGINATE MATRIX IN SOIL UNDER LABORATORY CONDITIONS
}

Abstract. The influence of humidity and soil type on the degradation process of clomazone, metazachlor and pendimethalin immobilized in the alginate matrix were studied under laboratory conditions, and herbicidal degradation parameters obtained for alginate systems and commercial formulations (Command 480 EC, Metazachlor 500 SC and Panida 330 SC) were compared. Two soils with different organic content were used in the experiment: loamy sand (S1) and sand (S2). The effect of soil humidity on the rate of herbicide degradation was assessed for soil S1 at $15 \%$ and $60 \%$ of maximum water holding capacity. Herbicides residues were analyzed using GC/MS method. The experimental data were fitted to the mathematical model based on the first-order reaction kinetics. There was no significant effect of soil type on the degradation rate of herbicides immobilized in the alginate matrix. For all alginate systems analyzed process was faster with an increased soil moisture. Formulation is a significant factor affecting the degradation process of herbicides in soil.

Keywords: herbicides, formulation, alginate matrix, degradation, humidity, soil

* West Pomeranian University of Technology in Szczecin, Faculty of Environmental Management and Agriculture, Department of General Chemistry, Microbiology and Environmental Biotechnology, ul. Słowackiego 17, 71-176 Szczecin, Poland; Corresponding author: e-mail: malgorzata. wlodarczyk@zut.edu.pl 


\section{INTRODUCTION}

Pesticides are the group of chemical compounds widely used in modern agriculture to increase efficiency and quality of agricultural production by reducing losses due to pests and weeds on cultivated land. One of the most important characteristics of pesticides granting marketing and use authorisation is their persistence in the environment (Grygiel et al. 2012). Pesticide persistence determines not only the efficiency of the preparation but also affects the quality of the natural environment and safety of the agricultural product for consumption (Wrzosek et al. 2009).

Pesticide degradation, in particular elements of the environment, is a complex process including various physical, chemical and biological processes. The rate and domination of certain processes depend on a number of factors, the most significant being physicochemical properties of an active substance, its formulation, dose and environmental conditions such as the type of soil, moisture, organic matter content, $\mathrm{pH}$, temperature and biological activity (Mervosh et al. 1995, Van der Werf 1996, Pal et al. 2006, Arias-Estevez et al. 2008, Włodarczyk and Siwek 2016).

To increase safety of pesticide use and minimise their negative effect on the environment, a series of new solutions is being introduced, the dominant being the use of adjuvants (Foster et al. 2006, Kucharski and Sadowski 2009, Green and Beestman 2007, Kucharski et al. 2012), ionic liquids (Pernak et al. 2011, Pernak et al. 2015) and innovative controlled release formulations. The key objective in the use of such formulations in agriculture is the gradual (controlled) release of the active substance to the environment and, at the same time, minimizing the applied dose (Mogul et al. 1996, Flores-Céspedes et al. 2007, Fernández-Pérez et al. 2011). Natural polymers such as alginate, ethylcellulose, starch, lignin and chitosan play a substantial role in controlled release technology due to their availability, low price, non-toxicity and, primarily, biological degradability (Roy et al. 2014).

The aim of the present research was to determine the influence of moisture and soil texture on degradation of clomazone, metazachlor and pendimenthalin immobilized in alginate matrix and comparison of herbicide degradation parameters of alginate systems with commercial preparations.

\section{MATERIALS AND METHODS}

Three herbicides were used in the course of the research: clomazone, metazachlor and pendimethalin. The basic criterion of active substance selection was varied solubility in water, which at $20^{\circ} \mathrm{C}$ was: clomazone $1,102 \mathrm{mg} / \mathrm{L}$, metazachlor $430 \mathrm{mg} / \mathrm{L}$, pendimethalin $0.33 \mathrm{mg} / \mathrm{L}$ (http://sitem.herts.ac.uk/aeru/ppdb/en/atoz. 
$\mathrm{htm})$. Alginate matrix formulations were obtained from the Centre for Bioimmobilization and Innovative Materials, West Pomeranian University of Technology in Szczecin, Poland (Włodarczyk et al. 2010). Metazachlor used in the research showed $98.6 \%$ purity and was provided by Feinchemie Schwebda GmbH (Germany), whereas pendimethalin (purity 97.1\%) and clomazone (purity 99.9\%) were obtained from a Chemical Plant "Organika-Sarzyna" (Poland). Commercial preparations Panida 330 EC, Metazachlor 480 SC, Command 480 EC were provided by IOR-PIB in Poznań.

The two types of soil used in the research were sampled from the Western Pomerania Region, Poland (S1 - Zaspy Małe 5403'32.07" N, 16¹6'27.66" E, S2 - Sławoszewo 5351'11.40" N, 14²4'58.95" E). Soil samples were selected according to their content of the organic carbon $(\mathrm{S} 1=0.83 \%, \mathrm{~S} 2=1.99 \%)$ and collected at a 0-20 cm depth, air dried, homogenized and passed through a 2.0 $\mathrm{mm}$ sieve. The physicochemical and soil texture characteristics of these soils are given in Table 1.

TABLE 1. SELECTED PROPERTIES OF SOILS

\begin{tabular}{cccccccccc}
\hline \multirow{2}{*}{ Soil } & $\begin{array}{c}\text { Granulometric } \\
\text { group }\end{array}$ & $\begin{array}{c}\text { Water holding } \\
\text { capacity }\end{array}$ & $\begin{array}{c}\text { Organic } \\
\text { carbon }\end{array}$ & $\mathrm{pH}$ & $\mathrm{Hh}$ & $\mathrm{CEC}$ & $\mathrm{TEB}$ & $\mathrm{BS}$ \\
\cline { 2 - 11 } & {$[\%]$} & {$[\%]$} & $\mathrm{H}_{2} \mathrm{O}$ & $\mathrm{KCl}$ & & $\mathrm{cmol} / \mathrm{kg}$ & & {$[\%]$} \\
\hline $\mathrm{S} 1$ & loamy sand & 34.63 & 0.83 & 5.56 & 4.28 & 3.33 & 16.10 & 19.43 & 82.88 \\
\hline $\mathrm{S} 2$ & sand & 37.18 & 1.99 & 4.56 & 3.71 & 10.33 & 15.30 & 25.63 & 59.71 \\
\hline
\end{tabular}

Hh - hydrolytic acidity; CEC - cation exchange capacity; TEB - total exchangeable bases; BS - base saturation

The effect of soil moisture on degradation of clomazone, metazachlor and pendimethalin immobilized in alginate matrix was assessed using loamy sand (S1). The experiment was conducted at two soil moisture levels: 15\% mwhc (H1) and 60\% mwhc (H2) (mwhc - maximum water holding capacity). The influence of soil type on degradation of the herbicide under analysis was assessed using two soil types: loamy sand (S1) and sand (S2) at 15\% mwhe water content.

At the same time, for comparative purposes, degradation of clomazone, metazachlor and pendimethalin from commercial preparations: Command $480 \mathrm{EC}$, Metazachlor 500 SC, Panida 330 EC, were analysed. Soil S1 at 15\% mwhc (H1) was used in analyses of commercial formulations.

For each analysed combination, $200 \mathrm{~g}$ of soil was used and brought to the appropriate moisture content (all determinations were conducted in three repetitions). The same dose of herbicide, $1.0 \mathrm{mg}$ of active substance $/ \mathrm{kg}$ of soil, was used in each of the analysed systems.

The analyses were conducted under laboratory conditions at the temperature of $20 \pm 2^{\circ} \mathrm{C}$, in the absence of light (Memmert incubator). During the experiment, 
soil moisture content was monitored by means of gravimetric method. The residues of active substances were identified following 1, 3, 5, 10, 20 and 30 days of the experiment.

Gas chromatography was used to determine the concentrations of herbicides in soil samples. PerkinElmer Clarus 600 gas chromatograph was equipped with an MS detector and Elite $5 \mathrm{MS}$ column $(30 \mathrm{~m} \times 0.25 \mathrm{~mm}, 0.5 \mu \mathrm{m}$ film thickness). To determine clomazone, metazachlor and pendimethalin in the samples, the electronic ionization method, type EI+, was used. Qualitative analysis was based on mass spectrum and ions characteristic for herbicides: clomazone 125, 204 and 239; metazachlor 81, 133, 209 and 277; pendimethalin 162, 252 and 281. Quantitative analysis was performed by the comparative method, based on the calibration curves (pendimethalin $\mathrm{y}=399988 \cdot \mathrm{x}-162.09 ; \mathrm{n}=6 ; \mathrm{R}^{2}=0.9988$; metazachlor $\mathrm{y}=358809 \cdot \mathrm{x}-282.04 ; \mathrm{n}=7 ; \mathrm{R}^{2}=0.9995 ;$ clomazone $\mathrm{y}=1.0 \cdot 10^{+6} \cdot \mathrm{x}-434.12$; $\left.\mathrm{n}=6 ; \mathrm{R}^{2}=0.9991\right)($ Włodarczyk 2016).

Statistical analysis of the obtained data was performed using STATISTICA 10 software. For the purpose of determining the effect of moisture and soil texture on degradation of the selected herbicides immobilized in alginate matrix, one-way analysis of variance (ANOVA) was used. Mean concentrations of herbicide obtained on particular days of the experiment were compared using the Tuckey test (statistical significance $p=0.05$ ) and presented in a graphs in the form of $\%$ of active substance residue \pm standard deviation. The results were elaborated using the first-order kinetics reaction model (eq. 1) which allowed determination of herbicide degradation rate constant $(k)$, time for $50 \%$ decay $\left(\mathrm{DT}_{50}\right)$ and $90 \%$ decay $\left(\mathrm{DT}_{90}\right)$. Constant $k$ was determined with the LevenbergMarquardt nonlinear estimation method.

$$
C_{0}=C_{t} \cdot e^{-k \cdot t}
$$

where: $C_{0}-$ initial concentration; $C_{t}-$ concentration at time $t ; k$ - constant of rate degradation ; $t$ - time.

\section{RESULTS}

The results obtained for the analysed herbicides meet the requirements of research on residues of plant protection products, and conform with the procedures laid down in EU document on validation of analytical methods and procedures for pesticide residues (Method 2011). The values of obtained standard deviation $\left(S_{D}\right)$ and coefficient of correlation $(V)$ for particular means representing measure of dispersion did not exceed $20 \%$ for a given series of measurements and amounted to: $S_{D}$ from $0.39 \%$ to $12.54 \%, V$ from $0.51 \%$ to $14.75 \%$. The used mathematical model, based on the first-order kinetics reaction, accu- 
rately describes processes of degradation of herbicides in soil. This is confirmed by high values of correlation coefficient obtained for the analysed substances extreme values from 0.917 to 0.974 (Table 2).

Based on the conducted research it was found that the analysed factors: soil moisture and soil texture, have a varied effect on degradation of the analysed herbicides immobilised in alginate matrix, under laboratory conditions. The greatest impact on degradation of herbicides immobilised in alginate matrix was found for soil moisture content. The analyses conducted on loamy sand (S1) of organic carbon content $\mathrm{C}_{\text {org }}=0.89 \%$, soil moisture $15 \%(\mathrm{H} 1)$ and $60 \%(\mathrm{H} 2)$ mwhe show that an increased water content in the soil increased the rate of degradation of herbicides immobilized in alginate matrix (Figs. 1a-3a). After 30 days of the experiment, in soil S1 of $\mathrm{H} 2$ moisture content, approximately $69.9 \%$ of clomazone $(\mathrm{H} 1=41.2 \%), 50 \%$ of metazachlor $(\mathrm{H} 1=32.05 \%)$ and $42 \%$ of pendimethalin $(\mathrm{H} 1=31.23 \%)$ were degraded. Differences between the content of active substance in $\mathrm{H} 1$ and $\mathrm{H} 2$ were significant for metazachlor and clomazone, according to the Tuckey test $(p=0.05)$, following 5, 10, 20 and 30 days of the experiment, whereas for pendimethalin only on the $30^{\text {th }}$ day of the experiment. Increased soil moisture at the level of $60 \%$ mwhc resulted in an increase of degradation rate constant $(k)$ for all analysed herbicide substances - by $77 \%$ for pendimethalin, $91 \%$ for metazachlor and as much as $117 \%$ for clomazone. Consequently, the analyses conducted on loamy sand of $60 \%$ mwhc water content showed the shortest degradation times $\left(\mathrm{DT}_{50}\right.$ and $\mathrm{DT}_{90}$ ) of the herbicides under analysis (Table 2).

\section{TABLE 2. PARAMETERS OF HERBICIDES DEGRADATION IN SOIL UNDER LABORATORY CONDITIONS}

\begin{tabular}{|c|c|c|c|c|c|c|}
\hline Combination & Soil & $\begin{array}{l}\text { Soil humidity } \\
\text { (\% of mwhc)* }\end{array}$ & $\begin{array}{c}\text { Constant } k \\
\left(\text { day }^{-1}\right)\end{array}$ & $\begin{array}{l}\mathrm{TD}_{50} \\
\text { (day) }\end{array}$ & $\begin{array}{l}\mathrm{TD}_{90} \\
\text { (day) }\end{array}$ & $\mathrm{R}^{2}$ \\
\hline \multicolumn{7}{|c|}{ Clomazone $(\mathrm{C})$} \\
\hline Command 480EC & S1 & 15 & 0.027 & 25.7 & 85.3 & 0.954 \\
\hline C_alginate capsules & S1 & 15 & 0.018 & 38.5 & 127.9 & 0.974 \\
\hline C_alginate capsules & S1 & 60 & 0.039 & 17.8 & 59.0 & 0.961 \\
\hline C_alginate capsules & $\mathrm{S} 2$ & 15 & 0.020 & 34.7 & 115.1 & 0.947 \\
\hline \multicolumn{7}{|c|}{ Metazachlor (M) } \\
\hline Metazachlor $500 \mathrm{SC}$ & $\mathrm{S} 1$ & 15 & 0.012 & 57.8 & 191.9 & 0931 \\
\hline M_alginate capsules & S1 & 15 & 0.011 & 63.0 & 209.3 & 0.949 \\
\hline M_alginate capsules & S1 & 60 & 0.021 & 33.0 & 109.6 & 0.932 \\
\hline M_alginate capsules & S2 & 15 & 0.011 & 63.0 & 209.3 & 0.943 \\
\hline \multicolumn{7}{|c|}{ Pendimethalin $(\mathrm{P})$} \\
\hline Panida 330 EC & $\mathrm{S} 1$ & 15 & 0.012 & 57.8 & 191.9 & 0.917 \\
\hline $\mathrm{P}$ _alginate capsules & $\mathrm{S} 1$ & 15 & 0.009 & 77.0 & 255.8 & 0.962 \\
\hline $\mathrm{P}$ _alginate capsules & $\mathrm{S} 1$ & 60 & 0.016 & 43.3 & 143.9 & 0.957 \\
\hline $\mathrm{P}_{\text {_ alginate capsules }}$ & $\mathrm{S} 2$ & 15 & 0.011 & 63.0 & 209.3 & 0.937 \\
\hline
\end{tabular}

* mwhc - maximum water holding capacity 

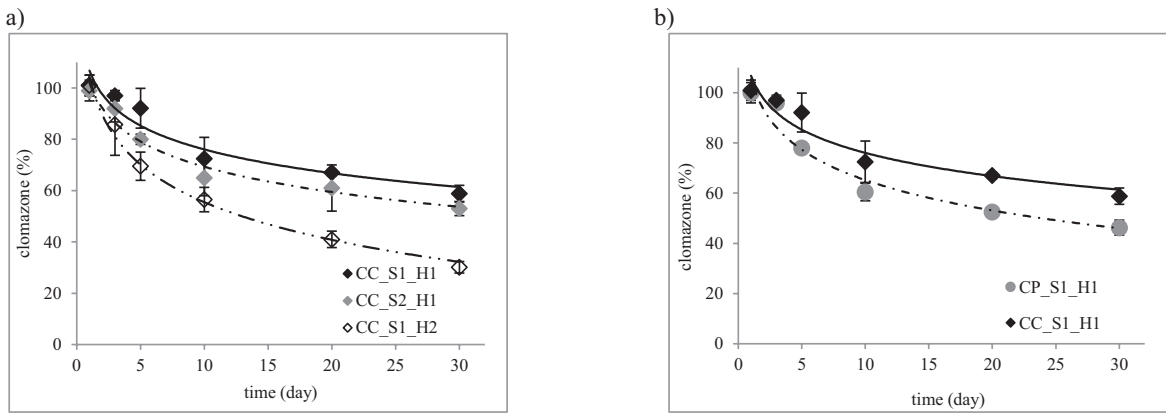

Fig. 1. Clomazone degradation in soil - laboratory conditions

a) influence of humidity and soil texture on the degradation process of clomazone immobilized in the alginate matrix

b) influence of formulation on the degradation process of clomazone in soil

$\mathrm{CC}$ - alginate capsules of clomazone; $\mathrm{CP}$ - formulation Command $480 \mathrm{EC}$

a)

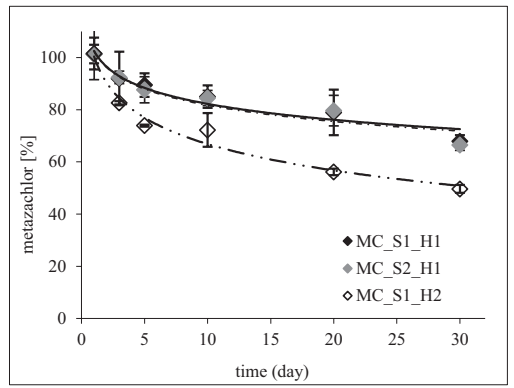

b)

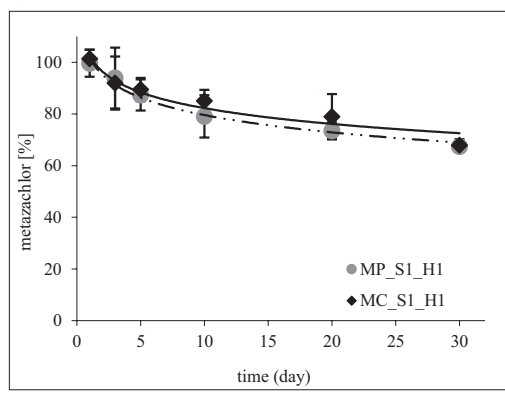

Fig. 2. Metazachlor degradation in soil - laboratory conditions

a) influence of humidity and soil texture on the degradation process of metazachlor immobilized in the alginate matrix

b) influence of formulation on the degradation process of metazachlor in soil

$\mathrm{MC}$ - alginate capsules of metazachlor; MP - formulation Metazachlor $500 \mathrm{SC}$

The analyses conducted on loamy sand (S1) and sand (S2) indicate only little effect of the texture of soil on degradation of herbicides immobilized in alginate matrix. A statistically significant difference (Tuckey test) between soils S1 and S2 in the active substance content was found only for clomazone on individual days of the experiment (following day 5 and 30) (Fig. 1a). Within 30 days of the experiment on S2 soil, $47 \%$ of the used clomazone dose was degraded, $6 \%$ more than on soil S1. Moreover, clomazone degradation rate constant showed higher values for soil S2 $\left(\mathrm{S} 1=0.018 \mathrm{day}^{-1} ; \mathrm{S} 2=0.020\right.$ day $\left.^{-1}\right)$. Consequently, degradation times $\mathrm{DT}_{50}$ and $\mathrm{DT}_{90}$ were shorter in sand than in loamy sand (Table 2). However, no influence of physicochemical properties of soil on degradation of metazachlor and pendimethalin immobilized in alginate matrix was found. Degradation of the two aforementioned herbicides in loamy sand 
and sand of $15 \%$ mwhe water content showed the same efficiency. Within 30 days of the experiment, $32.05 \%$ (S1) - 33.5\% (S2) of metazachlor and $31.2 \%$ (S1) $-30.6 \%(\mathrm{~S} 2)$ of pendimethalin was degraded. In the case of metazachlor, it was found that degradation rate constant $\left(k=0.011\right.$ day $\left.^{-1}\right)$, and therefore $\mathrm{DT}_{50}$ and $\mathrm{DT}_{90}$ times $\left(\mathrm{DT}_{50}=63\right.$ days, $\mathrm{DT}_{90}=209$ days), were the same for both soil types. As for pendimethalin, the increase of degradation rate on sand (S2) recorded in the initial period of the experiment (Fig. 3a) resulted in higher values of degradation rate constant $(k)$ by $18 \%$ in soil S2, despite the lack of statistically significant differences between the analysed combinations. As a result, $\mathrm{DT}_{50}$ and $\mathrm{DT}_{90}$ of pendimethalin in $\mathrm{S} 2$ were shorter.

a)

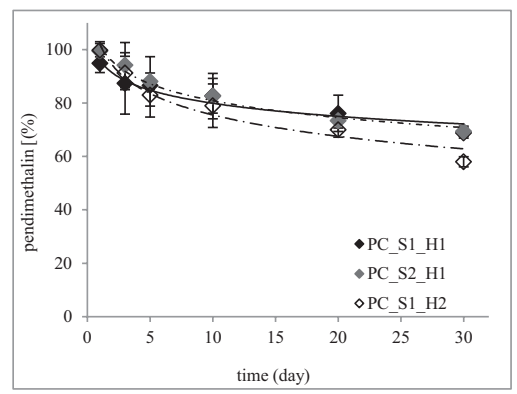

b)

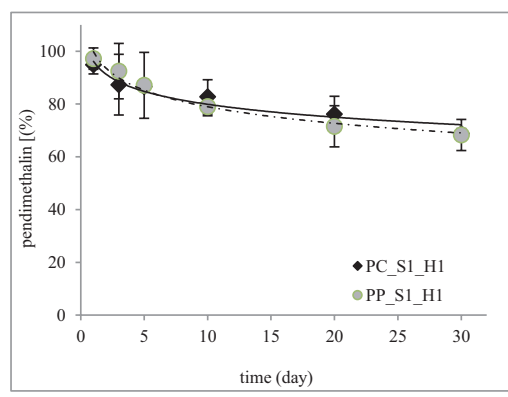

Fig. 3. Pendimethalin degradation in soil - laboratory conditions

a) influence of humidity and soil texture on the degradation process of pendimethalin immobilized in the alginate matrix

b) influence of formulation on the degradation process of penimethalin in soil

PC - alginate capsules of pendimethalin; PP - formulation Panida 330 EC

The analyses on the effect of formulation on the rate of degradation of the analysed herbicides in soil conducted for comparative purposes under laboratory conditions indicate that formulation is an additional factor affecting the process. The statistical analysis based on the Tuckey test at $p=0.05$ confirmed significant variations in the content of the analysed active substance between formulations for clomazone (alginate capsule, Command $480 \mathrm{EC}$ ) on day 5, 10, 20 and 30 of the experiment (Fig. 1b). In the case of metazachlor (alginate capsule, Metazachlor 500 SC) and pendimethalin (alginate capsule, Panida 330 EC), the differences were statistically insignificant in the course of the whole experiment (Figs. 2b, 3b). The results show that the use of alginate matrix slowed down the process of clomazone degradation in soil S1 of $15 \%$ mwhe moisture content. Despite the lack of significant variations between used formulations, it was found that in the case of metazachlor and pendimethalin, the rate of herbicide degradation was slightly higher in commercial preparation (Metazachlor 500 SC, Panida 330 EC). This is also reflected by the values of degradation rate constant $(k)$ obtained with the use of Levenberg-Marquardt nonlinear estimation 
(Table 2). The values of $k$ constant of herbicides immobilized in alginate matrix are higher: $9 \%$ metazachlor, $25 \%$ pendimethalin and $33.3 \%$ clomazon. Consequently, the time for $50 \%\left(\mathrm{DT}_{50}\right)$ and $90 \%\left(\mathrm{DT}_{90}\right)$ decay were higher for the alginate matrix preparations. The lowest difference in terms of $\mathrm{DT}_{50}$ between formulations was found for metazachlor - 9\% (alginate capsule, 63 days, Metazachlor $500 \mathrm{SC}, 57.8$ days). For penidmethalin and clomazone, the variations were higher. Clomazone degradation time $\mathrm{DT}_{50}$ of the alginate formulation amounted to 38.5 days and was by almost 13 days longer than $\mathrm{EC}$ formulation (25.7 days), whereas $\mathrm{DT}_{50}$ of pendimethalin was: 77 days alginate capsule, 57.8 days Panida EC. This correlation is confirmed by $\mathrm{DT}_{90}$ times: metazachlor 192 days $(\mathrm{EC})-$ 209 days (capsule), pendimethalin 209 days (SC) - 256 days (capsule), clomazon 167 days (EC) - 250 days (capsule).

\section{DISCUSSION}

The European regulations clearly identify the lines of scientific research to be conducted on commercial agrochemicals. One of the primary aspects of such research is determination of the impact of the substances on the environment. Herbicides reaching the soil and not absorbed by the root system undergo complex transformations influenced by various physical, chemical and biological factors. The results show that the rate of degradation and residence time of herbicides in soil is varied. This depends on the type of active substance, its water solubility being the determining factor. Out of the three analysed herbicide substances immobilized in alginate matrix, the shortest degradation time $\left(\mathrm{DT}_{50}=38.5\right.$ days and $\mathrm{DT}_{90}=127.9$ days) was found for clomazone which is characterised by the highest solubility in water $1,102 \mathrm{mg} / \mathrm{L}$. An increase in soil moisture to $60 \%$ mwhe significantly increased the rate of herbicide degradation process. This observation is also confirmed by studies conducted by Kucharski and Sadowski (2006) in which an increase in soil moisture from $20 \%$ mwhc to $90 \%$ mwhc resulted in a $70 \%$ shortening of $\mathrm{DT}_{50}$ of fluazifop-P, ethofumesate and chlopyralid. In the case of alginate matrix, an increase in soil moisture resulted in an intensification of the process of releasing herbicide substance to soil solution in which the substances underwent direct degradation (Flores-Céspedes et al. 2007, Fernández-Pérez et al. 2011,Włodarczyk and Buchwał 2015, Włodarczyk and Siwek 2016). For all alginate systems, at soil moisture $60 \%$ mwhc, degradation times were shorter by approximately $40 \%$ (pendimethalin) - 50\% (clomazone). The results show that degradation of herbicide substances immobilized in polymer matrix is less dependent on the texture of soil. The variations in the rate of degradation found between lamy sand and sand at 15\% mwhe were almost insignificant. Greater influence on degradation was found regarding herbicide formulation. The rate of degradation of clomazone, metazachlor and pendimethalin applied in the form of 
commercial formulation (Panida 330 EC, Metazachlor 500 SC, Command 480 $\mathrm{EC}$, respectively) was found to be slightly higher. Degradation rate constant calculated for commercial systems were higher. As a result, $\mathrm{DT}_{50}$ and $\mathrm{DT}_{90}$ times were shorter in the aforementioned formulations.

The results show that the use of polymer matrix allows reduction of the content of active substances in soil solution. This, in turn, would enable lengthening of duration of herbicide action, minimising the dosage and limiting environmentally hazardous leeching processes.

\section{CONCLUSIONS}

1. Soil moisture has a significant effect on degradation of herbicide immobilized in alginate matrix. An increased water content in soil resulted in increasing rate of the degradation process. Consequently, in soil of higher humidity obtained degradation times $\mathrm{DT}_{50}$ and $\mathrm{DT}_{90}$ were shorter for all analysed herbicides.

2. No significant effect of the soil type on the rate of degradation of herbicides immobilized in alginate matrix was found. The differences in the rate of degradation between loamy sand and sand at $15 \%$ maximum water holding capacity were practically insignificant.

3. It was found that formulation is the determining factor of herbicide degradation process in soil. The use of alginate matrix slows down the degradation process in soil.

\section{ACKNOWLEDGEMENT}

The chromatograph Clarus 600 by PerkinElmer was purchased within the framework of a project no OR16-61535-OR1600021/07 under the Sectoral Operational Programme of "Fisheries and Fish Processing 2004-2006".

The research was conducted within the framework of a grant of the Ministry of Science and Higher Education, Poland no. NN 305151433.

\section{REFERENCES}

[1] Arias-Estevez, M., Lopez-Periago, E., Martinez-Carballo, E., Simal-Gandara, J., Mejuto, J.C., Garcia-Rio, L., 2008. The Mobility and Degradation of Pesticides in Soils and the Pollution of Groundwater Resources. Agric. Ecosyst. Environ., 123: 247-260.

[2] Fernández-Pérez, M., Garrido-Herrera, F.J., González-Pradas, E., 2011. Alginate and Lignin-Based Formulations to Control Pesticides Leaching in a Calcareous Soil. J. Hazard. Mater., 190: 794-801. 
[3] Flores-Céspedes, F., Villafranca-Sánchez, M., Pérez-Garcia, S., Fernández-Pérez, M., 2007. Modifying Sorbents in Controlled Release Formulations to Prevent Herbicides Pollution. Chemosphere, 69: 785-794.

[4] Foster, D.K., Taylor, W.A., Parsons, R.G., 2006. Effects of Adjuvants on the Deposition, Retention and Efficacy of Pesticides. Aspects Appl. Biol., 77, 1: 127-132.

[5] Green, J.M., Beestman, G.B., 2007. Recently Patented and Commercialized Formulation and Adjuvant Technology. Crop Prot., 26: 320-327.

[6] Grygiel, K., Sadowski, J., Snopczyński, T., Wysocki, A., 2012. Herbicide Residues in Agricultural Products and in the Soil (in Polish). J. Eco. Health, 16, 40: 159-163.

[7] http://sitem.herts.ac.uk/aeru/ppdb/en/atoz.htm (access: 20.11.2016).

[8] Kucharski, M., Sadowski, J., 2006. Influence of soil Humidity on Herbicide Degradation Laboratory tests (in Polish). Prog. Plant Prot.,/Post. Ochr. Roślin, 46, 2: 750-753.

[9] Kucharski, M., Sadowski, J., 2009. Influence of Adjuvants on Behavior of Phenmedipham in Plant and Soil, Polish J. Agron., 1: 32-36.

[10] Kucharski, M., Sadowski, J., Domaradzki, K., 2012. Degradation Rate of Chloridazon in Soil as Influenced by Adjuvants, J. Plant Prot. Res., 52, 1: 115-150.

[11] Mervosh, T.L., Sims, G.K., Stoller, E. W., 1995. Clomazone Fate in Soil as Affected by Microbal Activity, Temperature and soil Moisture. J. Agric. Food Chem., 43: 537-543.

[12] Method validation and quality control procedures for pesticide residues analysis in food and feed, 2011. Document No. SANCO/ 12495/2011. Supersedes Document No. SANCO/10684/2009. Implemented by 01.01.2012 (access: 20.11.2016).

[13] Mogul, M.G., Akin, H., Hasirci, N., Trantolo, D.J., Gresser, J.D., Wise, D.L., 1996. Controlled Release of Biologically Active Agents for Purposes of Agricultural Crop Management. Resour. Conserv. Recy., 16: 289-320.

[14] Pal, R., Chakrabarti, K., Chakraborty, A., Chowdhury, A., 2006. Degradation and Effects of Pesticides on Soil Microbiological Parameters - Review. Int. J. Agri. Res., 1, 3: 240-258.

[15] Pernak, J. Syguda, A., Janiszewska, D., Materna, K., Praczyk, T., 2011. Ionic Liquids with Herbicidal Anions. Tetrahedron, 67: 4838-4844.

[16] Pernak, J., Niemczak, M., Shamshina, J.L., Gurau, G., Głowacki, G., Praczyk, T., Marcinkowska, K., Rogers, R.D., 2015. Metsulfuron-Methyl-Based Herbicidal Ionic Liquids. J. Agr. Food Chem., 13: 3357-3366.

[17] Roy, A., Singh, S.K., Bajpai, J.B., Bajpai, A.K., 2014. Controlled Pesticide Release from Biodegradable Polymers. Cent. Eur. J. Chem., 12: 453-469.

[18] Van der Werf, H.M.G. 1996. Assessing the Impact of Pesticides on the Environment. Agric. Ecosyst. Environ., 60: 81-96.

[19] Włodarczyk, M., Muszyńska, A., Siwek, H., Bartkowiak, A., 2010. Optimization of Production and Characterization of Hydrogel Microcapsules with Controlled Release of Selected Herbicides (in Polish). Przem. Chem., 4, 581-586.

[20] Włodarczyk, M., Buchwał, A., 2015. The Behavior of Metazachlor and Clomazone Immobilized in Alginate Matrix in Water/Soil and Water/Bottom Sediment Systems (in Polish). Przem. Chem., 94, 6: 989-993.

[21] Włodarczyk, M., Siwek, H., 2016. Influence of Formulation on Mobility of Clomazone in Soil. Bull. Environ. Contam. Toxicol., 97, 4: 582-587.

[22] Włodarczyk, M., 2016. Influence of the Alginate Matrix on the Decay of the Selected Herbicides in the Soil Under Field Conditions (in Polish). Prog. Plant Prot.,/Post. Ochr. Roślin 56, 3: 324-329.

[23] Wrzosek, J., Gworek, B., Maciaszek, D., 2009. Plant Protection Products and Environmental Protection (in Polish). Ochr. Śr. Zasobów Nat., 39: 75-88. 